\title{
Closed soilless growing system for producing strawberry bare root transplants and runner tips
}

\author{
Gustavo Giménez ${ }^{(1)}$, Jerônimo Luiz Andriolo(2), Djeimi Janisch(2) and Rodrigo Godoi(2) \\ (1)Instituto Nacional de Investigación Agropecuaria, Las Brujas, Ruta 48, Km 10, Rincón del Colorado, Canelones, Uruguay. \\ E-mail: gustav_gimenez@yahoo.com.br (2)Universidade Federal de Santa Maria, Departamento de Fitotecnia, Campus Camobi, \\ CEP 97105-900 Santa Maria, RS, Brazil. E-mail: jeronimo@pq.cnpq.br, djeimi_agro@yahoo.com.br, godoi@mail.com.br
}

\begin{abstract}
The objective of this work was to test a closed soilless growing system for producing bare root transplants and runner tips of two strawberry clones, using two categories of substrates. The system used corrugated roofing panels of fiber-cement, over which a substrate layer was used as a growing bed. The nutrient solution was pumped from a reservoir toward the upper end of the roofing panels and drained back to a reservoir. Plant growth and development were determined for two advanced strawberry clones, grown in sand or in Plantmax organic substrate. Growth of the stock plants and the number and dry mass of bare root transplants were similar in the substrates, but bare roots differed in their crown diameters by substrate. For number of runner tips, no significant differences were found in total, small, and medium categories in the substrates. A mean production of about 590 runner tips per square meter and 145 bare root transplants per square meter was obtained. For both clones, a large number of bare root transplants and runner tips of adequate size were produced in the closed soilless growing system using sand or organic substrate.
\end{abstract}

Index terms: Fragaria ananassa, growth and development, inert substrate, nursery, organic substrate, plant propagation.

\section{Sistema fechado de cultivo sem solo para produção de mudas de raízes nuas e de pontas de estolões de morangueiro}

Resumo - O objetivo deste trabalho foi testar um sistema fechado de cultivo sem solo, para a produção de mudas e pontas de estolões de dois clones de morangueiro, com uso de duas categorias de substrato. O sistema foi constituído por um leito de cultivo formado por telhas de fibrocimento, com uma camada de substrato como leito de cultivo. A solução nutritiva foi bombeada de um reservatório até a extremidade mais alta da telha e drenada de volta ao reservatório. Foram determinados o crescimento e o desenvolvimento de dois clones avançados de morangueiro, plantados na areia e no substrato orgânico Plantmax. O crescimento das plantas matrizes foi similar nos dois substratos. O número e a massa de matéria seca das mudas de raízes nuas foram semelhantes nos dois substratos, mas diferiram nos diâmetros de coroa. Quanto ao número de pontas de estolões, não foram observadas diferenças significativas nas categorias pequena e média e no total, em ambos os substratos. Foram obtidas produções médias de 590 pontas de estolão por metro quadrado e 145 mudas de raízes nuas por metro quadrado. A produção de um alto número de mudas com raízes nuas e de pontas de estolão de morangueiro, com tamanho e peso adequados, pode ser realizada no sistema fechado sem solo, com uso de substratos inertes ou orgânicos.

Termos para indexação: Fragaria ananassa, crescimento e desenvolvimento, substrato inerte, viveiro, substrato orgânico, propagação de plantas.

\section{Introduction}

For strawberry propagation, disease-free plantlets are obtained in vitro and, after an acclimatizing period, stock plants are grown in nurseries for further production of transplants (Santos \& Medeiros, 2003). Strawberry plants for commercial fruit production have been grown in soils fumigated with methyl bromide. Methyl bromide has been banned due to its risk to the environment. Therefore, new propagation methods are needed to produce strawberry transplants with high physiological and sanitary quality.

Strawberry transplants may be bare root or plugs. Bare root transplants are obtained from runners rooted in the soil, while plug transplants are rooted in containers or trays filled with substrate. Plugs have the root system embodied by the substrate and have advantages in relation to crop stand, earliness, and disease and pest management. Plug production 
in media is being adopted in USA and Europe as an alternative to the use of methyl bromide (Bish et al., 2002; Durner et al., 2002; Lieten et al., 2004; Takeda et al., 2004; Hochmuth et al., 2006b).

For production of plug transplants, only runner tips grown in a short summer time period are used. In USA, certified stock plants are grown in spring in fumigated open field nurseries. In Europe, planting is done in plastic bags filled with peat and placed on raised beds mulched with a white polyethylene film. In both cases, runners spread out horizontally, and tips are harvested and planted in trays for rooting (Durner et al., 2002). Soilless suspended systems have been also developed to produce runner tips inside greenhouses (Bish et al., 2001; Takeda et al., 2004). These systems consist of elevated gutters with inert substrates and drip fertigation (Bish et al., 2001) or of the nutrient film technique (NFT) in gullies (Takeda et al., 2004).

In Brazil, only bare root transplants are grown in field without soil fumigation. As a consequence, transplant physiological and sanitary quality is low. The Brazilian strawberry industry depends on transplants imported from Argentina and Chile (Santos \& Medeiros, 2003).

Soilless growing systems are an alternative to avoid the use of fumigants in the production of strawberry transplants (Hennion \& Veschambre, 1997; Bish et al., 2001; Lieten et al., 2004). In Brazil, open soilless growing systems have been tested, but results have been inconsistent (Bueno, 2006; Oliveira et al., 2007). Closed nutrient cycling systems are preferable to open ones, in order to reduce production costs and avoid environmental pollution due to nutrient solution drainage and loss. The use of substrates is recommended for better root aeration, especially under high air temperatures (Andriolo, 2006), and for reducing pump wear (Giménez, 2007). The choice of the substrate should be based on physical characteristics as well as availability, cost, and lifespan (Hennion \& Veschambre, 1997; Lieten et al., 2004; Giménez et al., 2008). A closed soilless growing system using sand or organic substrate for producing potato minitubers was reported (Andriolo, 2006). Reports on the production of strawberry transplants on substrate with a closed nutrient system were not found in the literature.

The objective of this work was to determine the number and size of bare root transplants and runner tips of two strawberry clones grown in a closed soilless growing system, using two substrates.

\section{Materials and Methods}

The experiment was carried out in a screen house covered with a $120 \mu \mathrm{m}$ polyethylene film, at the Universidade Federal de Santa Maria (UFSM), Santa Maria county, Rio Grande do Sul state, Brazil, from October $15^{\text {th }}, 2005$, to March $15^{\text {th }}, 2006$. The soilless system used corrugated roofing panels of fiber-cement (Brasilit, São Paulo, SP, Brazil) at 1\% slope, to support a $0.015 \mathrm{~m}$ thick substrate growing bed, $0.80 \mathrm{~m}$ height above the ground. Dimensions of the panels were $3.5 \mathrm{~m}$ long and $1.10 \mathrm{~m}$ wide, with corrugates $0.06 \mathrm{~m}$ deep and spaced $0.18 \mathrm{~m}$ apart. A nutrient solution reservoir was located under the lower extreme of the panel. The panel corrugates were covered with a $100 \mu \mathrm{m}$ polyethylene sheet. The corrugates were then filled with $0.015-0.020 \mathrm{~m}$ diameter gravel and covered with a $0.0015 \mathrm{~m}$ polyethylene screen to hold the substrate on the bed. The nutrient solution was supplied to the growing bed by subirrigation. A timer-controlled $520 \mathrm{~L} \mathrm{~h}^{-1}$ submerse pump (8W, model S520, Sarlo Better Equipamentos, São Caetano do Sul, SP, Brazil) was used to circulate the nutrient solution from the reservoir to the upper end of the panel (Giménez, 2007).

Two substrates and two strawberry clones were evaluated in a completely randomized split plot design, with five replications, with substrates as main plots and clones as subplots. Each sub-plot consisted of a panel of the soilless system with $3.85 \mathrm{~m}^{2}$ and three stock plants. The advanced strawberry breeding clones LBD 15.1 and LBG 168.1, from the Strawberry Breeding Program of UFSM, were used. The substrates used were sand and a commercial organic substrate made with forest residues (Plantmax HA, Eucatex, Paulínia, SP, Brazil). Physical characteristics of sand were $0.001-0.003 \mathrm{~m}$ size particles, $1.6 \mathrm{~kg} \mathrm{dm}^{-3}$ bulk density and $0.199 \mathrm{~L} \mathrm{dm}^{-3}$ maximum water retention capacity. For Plantmax HA, bulk density was $0.405 \mathrm{~kg} \mathrm{dm}^{-3}$, and maximum water retention capacity $0,466 \mathrm{~L} \mathrm{dm}^{-3}$. Chemical analysis of Plantmax HA substrate, made at the UFSM Soil Laboratory according to Tedesco et al. (1995), showed $600 \mathrm{mg} \mathrm{dm}^{-3}$ $\mathrm{K}, 76 \mathrm{mg} \mathrm{dm}^{-3} \mathrm{P}, 128.1 \mathrm{mg} \mathrm{dm}^{-3} \mathrm{~S}, 14.3 \mathrm{cmol}_{\mathrm{c}} \mathrm{dm}^{-3}$ $\mathrm{Ca}, 5.6 \mathrm{Mg} \mathrm{cmol}_{\mathrm{c}} \mathrm{dm}^{-3}, 16.6 \%$ organic matter, and pH 5.1

The nutrient solution described by Hennion \& Veschambre (1997) was used. It contained $12 \mathrm{mmol} \mathrm{L}^{-1}$ $\mathrm{NO}_{3}^{-}, 2 \mathrm{mmol} \mathrm{L}{ }^{-1} \mathrm{NH}_{4}^{+}, 6.2 \mathrm{mmol} \mathrm{L}{ }^{-1} \mathrm{~K}^{+}, 2.2 \mathrm{mmol} \mathrm{L}^{-1}$ 


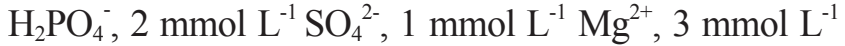
$\mathrm{Ca}^{2+}, 0.03 \mathrm{mg} \mathrm{L}^{-1} \mathrm{Mo}, 0.26 \mathrm{mg} \mathrm{L}^{-1} \mathrm{~B}, 0.06 \mathrm{mg} \mathrm{L}^{-1} \mathrm{Cu}$, $0.50 \mathrm{mg} \mathrm{L}^{-1} \mathrm{Mn}, 0.22 \mathrm{mg} \mathrm{L}^{-1} \mathrm{Zn}$ and $4 \mathrm{mg} \mathrm{L}^{-1}$ chelated Fe. The electrical conductivity of the nutrient solution was kept between 1.4 and $1.5 \mathrm{dS} \mathrm{m}^{-1}$ by adding either water or new amounts of nutrient solution, as necessary. The $\mathrm{pH}$ was kept between 5.5 and 6.5 by adding $1 \mathrm{~N} \mathrm{H}_{3} \mathrm{PO}_{4}$ or $\mathrm{KOH}$ solutions, every time a 0.2 unit deviation was recorded, based upon a titration curve. No nutrient solution disposal occurred during the course of the experiment.

The volume of nutrient solution delivered daily to plants was estimated from the water retention capacity of the substrate and the potential crop evapotranspiration (ET), with a drainage coefficient of $30 \%$. The ET was estimated and leaf area was obtained from data of horticultural crops locally grown in a similar environmental condition (Dalmago et al., 2006). The ET was further multiplied by the crop leaf area, estimated weekly from the growth pattern of the strawberry crop. With these estimations, the nutrient solution was delivered to plants during $15 \mathrm{~min}$, four times a day, in the Plantmax HA substrate, and six times a day, in the sand.

Strawberry stock plants were obtained from the Biotechnology Laboratory of UFSM and acclimated in a greenhouse. Planting was on October $15^{\text {th }}, 2005$, in the center of the bed, at a density of 1 stock plant per square meter. The experiment was ended 150 days later, when bare root transplants and runner tips were harvested. The final size of the stock plants was determined by dry mass of roots, crown, petioles and leaves. In the case of bare root transplants, number, total dry mass and crown diameter in 10 plants randomly sampled were measured. Dry mass was recorded after drying the plants in a forced air oven at $60^{\circ} \mathrm{C}$ until constant weight was reached. Runner tips were collected in a one-time harvest, counted and classified in three categories, according to the number of leaves and crown diameter (CD): small, with 2-3 leaves and 2 to $2.9 \mathrm{~mm}$ of CD; medium, with 3-4 leaves and 3 to $4.5 \mathrm{~mm}$ of $\mathrm{CD}$; and large, with 4-6 leaves and 4.6 to $6 \mathrm{~mm}$ of CD. Small runner tips, without signs of adventitious roots or too large with roots bigger than $1 \mathrm{~cm}$, were discarded (Durner et al., 2002).

Data were submitted to analysis of variance and the means were compared by Tukey's test, at 5\% probability. For number of bare root transplants and runner tips, the data were transformed using the expression $(\mathrm{x}+0.05)^{0.5}$ prior to performing the analysis of variance and Tukey's test.

\section{Results and Discussion}

No significant interactions were found between substrates and clones. Growth of stock plants was similar among treatments. Mean values were $15.4 \mathrm{~g}$ per plant, for total dry mass, and $11.7 \mathrm{~mm}$ for crown diameter. The relative fraction of total dry mass allocated in roots, crown, petioles and leaves was 0.10 , $0.16,0.32$ and 0.42 , respectively.

Means of bare root transplants differed between substrates only in the crown diameter that were thicker for those grown in sand (Table 1). The values of crown diameter in both substrates were in the acceptable range reported in the literature (Hochmuth et al., 2001, 2006a, 2006b; Durner et al., 2002). Between clones, differences were in number, dry mass and crown diameter. Higher number of bare root transplants was produced by the clone LBD 15.1, while higher total dry mass and crown diameter were observed in the clone LBG 168.1. The crown of the strawberry plant acts as a storage compartment (Hennion \& Veschambre, 1997). In the propagation phase, growth of young runners depends on assimilates from the stock plant. Thus, a competition might take place among runners of the stock plant and also between the crown of the stock plant and runners. Increasing the number of runners will increase the number of transplants per stock plant, but its crown diameter might be lower. These relations might have occurred here, since the total dry weight and crown diameter were smaller in the genotype LBD 15.1, which produced a higher number of transplants (Table 1).

Means of runner tips differed between substrates only in the large category (Table 2). The fractions of small, medium and large were $0.40,0.40$ and 0.20 in the sand and 0.33, 0.39 and 0.28 in the Plantmax HA, respectively. Between clones, runner tip numbers were

Table 1. Bare root strawberry transplant number, dry mass per transplant, and crown diameter grown in a closed soilless system with two substrates and two clones ${ }^{(1)}$.

\begin{tabular}{lccc}
\hline Treatment & $\begin{array}{c}\text { Total number } \\
\text { per stock plant }\end{array}$ & $\begin{array}{c}\text { Dry mass by } \\
\text { transplant }(\mathrm{g})\end{array}$ & $\begin{array}{c}\text { Crown diameter } \\
(\mathrm{mm})\end{array}$ \\
\hline $\begin{array}{l}\text { Substrates } \\
\quad \text { Sand }\end{array}$ & $140 \mathrm{a}$ & $4.73 \mathrm{a}$ & $\begin{array}{c}12.00 \mathrm{a} \\
\text { Plantmax HA }\end{array}$ \\
$150 \mathrm{a}$ & $5.02 \mathrm{a}$ & $10.32 \mathrm{~b}$ \\
\hline CV (\%) & 15.89 & 13.98 & 11.91 \\
\hline Clones & & & \\
$\quad$ LBD 15.1 & $166 \mathrm{a}$ & $3.99 \mathrm{~b}$ & $9.95 \mathrm{~b}$ \\
$\quad$ LBG 168.1 & $124 \mathrm{~b}$ & $5.74 \mathrm{a}$ & $12.37 \mathrm{a}$ \\
\hline CV (\%) & 16.61 & 8.07 & 4.98 \\
\hline
\end{tabular}

${ }^{(1)}$ Means followed by the same letters, in the column, do not differ by Tukey's test at $5 \%$ of probability.

Pesq. agropec. bras., Brasília, v.43, n.12, p.1757-1761, dez. 2008 
higher in LBD 15.1 for all categories. The production of runner tips is genetically determined and is related to the propagation ability of a cultivar (Guttridge, 1985), conditioning of the mother stock plant, and environmental conditions for vegetative reproduction. Runner tip production is used as a criterion to select cultivars in strawberry breeding programs. Present results showed that the substrate difference was of minor importance in the production of runner tips.

Runner tips are classified into categories because their initial size may affect the final crown diameter of the plug transplant. Crown diameter influences crop characteristics such as yield, early flowering and fruit production. Results from the literature suggested that runner tips heavier than $1 \mathrm{~g}$ (Takeda \& Hokanson, 2003; Takeda et al., 2004; Takeda \& Newell, 2006) or plug transplants with a minimum crown diameter of $8 \mathrm{~mm}$ (Hochmuth et al., 2006a, 2006b) are needed for high crop fruit productivity. In this research, runner tips were not weighted, but very small ones were discarded. Those used for rooting produced plug transplants with an average crown diameter of $9 \mathrm{~mm}$.

A mean yield of about 600 runner tips per square meter was obtained (Table 2). This number was within the range obtained by Hokanson et al. (2004) and Takeda et al. (2004) and it was lower than that of Bish et al. (2001), who used stock plants of commercial cultivars grown in suspended gutters. However, the latter authors used 32 stock plants per square meter. In the present experiment only 1 stock plant per square meter was used, which is an economic advantage because of the price of stock plants produced in vitro.

Table 2. Total number and number in each size category of strawberry runner tips grown in a closed soilless system with two substrates and two clones ${ }^{(1)}$.

\begin{tabular}{lcccc}
\hline Treatment & $\begin{array}{c}\text { Total number of } \\
\text { runner tips per } \\
\text { stock plant }\end{array}$ & \multicolumn{3}{c}{$\begin{array}{c}\text { Number of runner tips } \\
\text { per stock plant }\end{array}$} \\
\cline { 3 - 5 } & & Small & Medium & Large \\
\hline Substrates & $575 \mathrm{a}$ & $225 \mathrm{a}$ & $230 \mathrm{a}$ & $120 \mathrm{~b}$ \\
$\quad$ Sand & $635 \mathrm{a}$ & $208 \mathrm{a}$ & $247 \mathrm{a}$ & $180 \mathrm{a}$ \\
$\quad$ Plantmax HA & 10.27 & 15.75 & 10.72 & 15.69 \\
\hline CV (\%) & & & & \\
\hline Clones & $681 \mathrm{a}$ & $276 \mathrm{a}$ & $246 \mathrm{a}$ & $159 \mathrm{a}$ \\
$\quad$ LBD 15.1 & $498 \mathrm{~b}$ & $147 \mathrm{~b}$ & $218 \mathrm{~b}$ & $133 \mathrm{~b}$ \\
\multicolumn{1}{c}{ LBG 168.1 } & 15.20 & 12.72 & 6.23 & 13.08 \\
\hline CV $(\%)$ &
\end{tabular}

${ }^{(1)}$ Means followed by the same letters, in the column, do not differ by Tukey's test at $5 \%$ of probability. ${ }^{(2)}$ Small, medium, and large crown diameters for each corresponding size of plant based on the number of leaves: $3-3.9 \mathrm{~mm}$ for plants with 2 to 3 leaves; $4-5.5 \mathrm{~mm}$ for plants with 3 to 4 leaves; and 6-7 $\mathrm{mm}$ for plants with 4 to 6 leaves, respectively.

\section{Conclusions}

1. A high number of bare root transplants and runner tips of both clones with adequate size were produced in the closed soilless growing system using sand or organic substrate.

2. Substrate was of minor importance in the production of runner tips, but it may affect the crown diameter of bare root transplants.

\section{Acknowledgement}

To Conselho Nacional de Desenvolvimento Científico e Tecnológico for grant.

\section{References}

ANDRIOLO, J.L. Sistema hidropônico fechado com subirrigação para produção de minitubérculos de batata. In: SIMPÓSIO DE MELHORAMENTO GENÉTICO E PREVISÃO DE EPIFITIAS EM BATATA, 2006, Santa Maria, RS. Anais... Santa Maria: UFSM, 2006. p.26-40.

BISH, E.B.; CANTLIFFE, D.J.; CHANDLER, C.K. A system for producing large quantities of greenhouse grown strawberry plantlets for plug production. HortTechnology, v.11, p.636-638, 2001.

BISH, E.B.; CANTLIFFE, D.J.; CHANDLER, C.K. Temperature conditioning and container size affect early season fruit yield of strawberry plug plants in a winter, annual hill production system. HortScience, v.37, p.762-764, 2002.

BUENO, S.C.S. Produção de mudas em ambiente protegido. In: SIMPÓSIO NACIONAL DE MORANGO, 3.; ENCONTRO SOBRE PEQUENAS FRUTAS E FRUTAS NATIVAS DO MERCOSUL, 2., 2006, Pelotas. Palestras... Pelotas: Embrapa Clima Temperado, 2006. p.45-54. (Embrapa Clima Temperado. Documentos, 171).

DALMAGO, G.A.; HELDWEIN, A.B.; NIED, A.H.; GRIMM, E.L.; PIVETTA, C.R. Evapotranspiração máxima da cultura do pimentão em estufa plástica em função da radiação solar, da temperatura, da umidade do ar e do deficit de saturação do ar. Ciência Rural, v.36, p.785-792, 2006.

DURNER, E.F.; POLING, E.B.; MAAS, J.L. Recent advances in strawberry plug transplant technology. HortTechnology, v.12, p.545-550, 2002.

GIMÉNEZ, G. Produção de mudas de morangueiro em hidroponia. In: SEMINÁRIO SOBRE O CULTIVO HIDROPÔNICO DE MORANGUEIRO, 2007, Santa Maria, RS. Anais... Santa Maria: UFSM, 2007. p.18-29.

GIMÉNEZ, G.; ANDRIOLO, J.; GODOI, R. Cultivo sem solo do morangueiro. Ciência Rural, v.38, p.273-279, 2008.

GUTTRIDGE, C.G. Fragaria x ananassa. In: HALEY, A.H. (Ed.). CRC handbook of flowering, 1985. p.16-33.

HENNION, B.; VESCHAMBRE, D. La fraise: maîtrise de la production. Paris: CTIFL, 1997. 299p. 
HOCHMUTH, G.; CANTLIFFE, D.; CHANDLER, C.; STANLEY, C.; BISH, E.; WALDO, E.; LEGARD, D.; DUVAL, J. Containerized strawberry transplants reduce establishment-period, water use and enhance early growth and flowering compared with bare-root plants. HortTechnology, v.16, p.46-54, 2006 a.

HOCHMUTH, G.; CANTLIFFE, D.; CHANDLER, C.; STANLEY, C.; BISH, E.; WALDO, E.; LEGARD, D.; DUVAL, J. Fruiting responses and economics of containerized and bare root strawberry transplants established with different irrigation methods. HortTechnology, v.16, p.205-210, $2006 \mathrm{~b}$.

HOCHMUTH, G.; CHANDLER, C.; STANLEY, C.; LEGARD, D.; DUVAL, J.; WALDO, E.; CANTLIFFE, D.; BISH, E. Containerized transplants for establishing strawberry crops in Florida. HortScience, v.37, p.443, 2001.

HOKANSON, S.C.; TAKEDA, F.; ENNS, J.M.; BLACK, B.L. Influence of plant storage duration on strawberry runner tip viability and field performance. HortScience, v.39, p.1596-1600, 2004.

LIETEN, F.; LONGUESSERRE, J.; BARUZZI, G.; LOPEZMEDINA, J.; NAVATEL, J.C.; KRUEGER, E.; MATALA, V.; PAROUSSI, G. Recent situation of strawberry substrate culture in Europe. ISHS Acta Horticulturae, n.649, p.193-196, 2004.
OLIVEIRA, R.P.; BRAHM, R.; SCIVITTARO, W. Produção de mudas de morangueiro em casa de vegetação utilizando recipientes suspensos. Horticultura Brasileira, v.25, p.107-109, 2007.

SANTOS, A.M.; MEDEIROS, A.R.M. (Ed.). Morango: produção. Brasília: Embrapa Informação Tecnológica, 2003a. 81p. (Frutas do Brasil, 40).

TAKEDA, F.; HOKANSON, S.C. Strawberry fruit and plug plant production in the greenhouse. Acta Horticulturae, n.626, p.283-285, 2003.

TAKEDA, F.; HOKANSON, S.C.; ENNS, J.M. Influence of daughter plant weight and position on strawberry transplant production and field performance in annual plasticulture. HortScience, v.39, p.1592-1595, 2004.

TAKEDA, F.; NEWELL, M. A method to increasing fall flowering in short-day Carmine strawberry. HortScience, v.41, p.480-481, 2006.

TEDESCO, M.J.; GIANELLO, C.; BISSANI, C.A.; BOHNEN, H.; VOLKWEISS, S.J. Análise de solo, plantas e outros materiais. Porto Alegre: UFRGS, 1995. 173p.

Received on October 8, 2008 and accepted on November 28, 2008 